\title{
Puréed Foods and Fiber ${ }^{1}$
}

\author{
Wendy J. Dahl ${ }^{2}$
}

Fiber is important to good health. Inadequate fiber intake may lead to constipation and other gastrointestinal complaints. Diets high in fiber may help to lower cholesterol and blood glucose, reducing the risk of heart disease (1). Although fiber is found in all plant foods such as fruits, vegetables, beans, grains, nuts, and seeds, most people do not consume enough fiber. Recommended fiber intakes are shown in Table 1.

Table 1. Fiber recommendations by age (1)*

\begin{tabular}{|l|l|}
\hline Age & Fiber Recommendation \\
\hline Children 1-3 years & $19 \mathrm{~g}$ per day \\
\hline Children 4-8 years & $25 \mathrm{~g}$ per day \\
\hline Female 9-18 years & $26 \mathrm{~g}$ per day \\
\hline Males 9-13 years & $31 \mathrm{~g}$ per day \\
\hline Males 14-50 years & $38 \mathrm{~g}$ per day \\
\hline Females 19-50 years & $25 \mathrm{~g}$ per day \\
\hline Men > 50 years & $30 \mathrm{~g}$ per day \\
\hline Females $>50$ years & $21 \mathrm{~g}$ per day \\
\hline *Fiber recommendations are based on $14 \mathrm{~g}$ of fiber per 1,000 kcal \\
of energy intake (1).
\end{tabular}

\section{Do people with swallowing problems get enough fiber?}

People with swallowing problems who require a puréed diet may not meet their recommended intake of fiber. Studies have shown that older women living in long-term care consume only about $8 \mathrm{~g}$ of fiber per day and men only

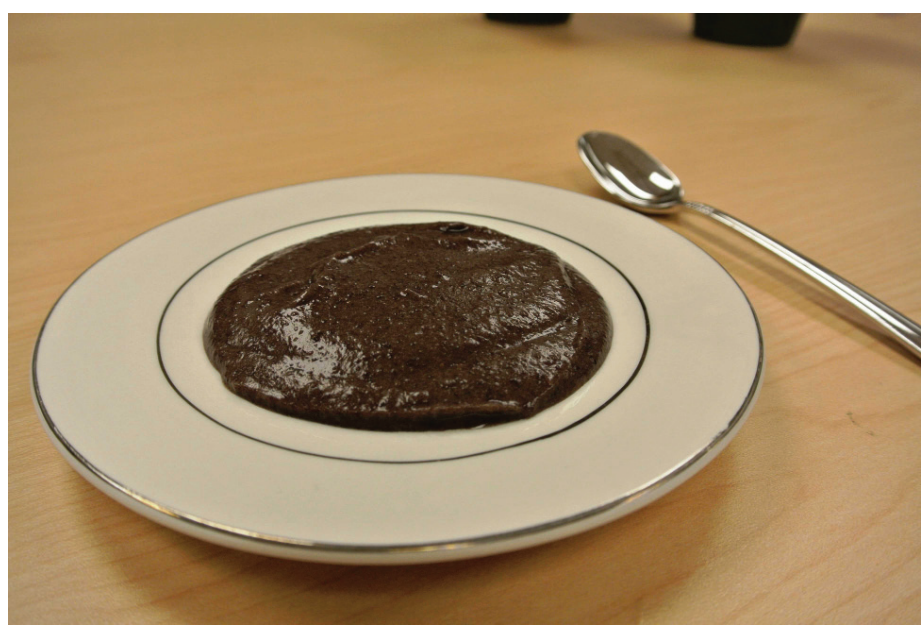

Figure 1. Puréed black beans Credits: UF/IFAS photo

$12 \mathrm{~g}$ (2), and it would be expected that those who consume puréed diets have similar intakes.

Many puréed foods naturally contain dietary fiber. Puréed beans, peas, and lentils are good sources of fiber. For example, a $1 / 4$-cup serving of hummus, prepared from puréed chickpeas, provides $2.5 \mathrm{~g}$ of fiber. Puréed fruits and vegetables are also sources of fiber, with $1 / 2$-cup servings providing, on average, about $2 \mathrm{~g}$ of fiber. Cooking does not change the amount of fiber in foods; cooked and puréed vegetables contain the same amount of fiber as raw vegetables do. Table 2 shows the fiber contents of some common puréed foods. Animal products such as milk, meats, fish, poultry, and eggs do not naturally contain fiber.

1. This document is FSHN12-16, one of a series of the Food Science and Human Nutrition Department, Florida Cooperative Extension Service, Institute of Food and Agricultural Sciences, University of Florida. Original publication date January 2013. Visit the EDIS website at http://edis.ifas.ufl.edu.

2. Wendy J. Dahl, assistant professor, Food Science and Human Nutrition Department, Institute of Food and Agricultural Sciences, University of Florda, Gainesville, FL 32611. 
Table 2. Fiber contents per serving size of common puréed foods (3)

\begin{tabular}{|c|c|c|c|}
\hline & & Serving Size & Fiber Content \\
\hline \multirow{3}{*}{ Protein Foods } & Baked beans - vegetarian, canned, puréed & $1 / 2$ cup $(125 \mathrm{~mL})$ & $5.2 \mathrm{~g}$ \\
\hline & Hummus & $1 / 4$ cup $(60 \mathrm{~mL})$ & $3.7 \mathrm{~g}$ \\
\hline & Refried beans - puréed & $1 / 2$ cup $(125 \mathrm{~mL})$ & $6.1 \mathrm{~g}$ \\
\hline \multirow{10}{*}{ Vegetables } & Squash - cooked, mashed & $1 / 2$ cup $(125 \mathrm{~mL})$ & $3.2 \mathrm{~g}$ \\
\hline & Sweet potato - canned, mashed & $1 / 2$ cup $(125 \mathrm{~mL})$ & $2.2 \mathrm{~g}$ \\
\hline & Mashed potatoes with butter and milk & $1 / 2 \operatorname{cup}(125 \mathrm{~mL})$ & $1.6 \mathrm{~g}$ \\
\hline & Beets - canned, mashed & $1 / 2 \operatorname{cup}(125 \mathrm{~mL})$ & $1.5 \mathrm{~g}$ \\
\hline & Creamed corn - canned, puréed & $1 / 2$ cup $(125 \mathrm{~mL})$ & $1.5 \mathrm{~g}$ \\
\hline & Carrots - cooked, puréed & $1 / 2$ cup $(125 \mathrm{~mL})$ & $3.2 \mathrm{~g}$ \\
\hline & Green beans & $1 / 2$ cup $(125 \mathrm{~mL})$ & $2.8 \mathrm{~g}$ \\
\hline & Peas & $1 / 2 \operatorname{cup}(125 \mathrm{~mL})$ & $2.4 \mathrm{~g}$ \\
\hline & Spinach purée & $1 / 4$ cup $(60 \mathrm{~mL})$ & $1.1 \mathrm{~g}$ \\
\hline & Vegetable juice & 1 cup $(250 \mathrm{~mL})$ & $1.9 \mathrm{~g}$ \\
\hline \multirow{7}{*}{ Fruits } & Applesauce - unsweetened & $1 / 2$ cup $(125 \mathrm{~mL})$ & $1.3 \mathrm{~g}$ \\
\hline & Avocado - puréed & $1 / 4$ cup $(60 \mathrm{~mL})$ & $3.9 \mathrm{~g}$ \\
\hline & Banana - mashed & $1 / 2$ cup $(125 \mathrm{~mL})$ & $2.9 \mathrm{~g}$ \\
\hline & Peach purée & $1 / 2 \operatorname{cup}(125 \mathrm{~mL})$ & $1.4 \mathrm{~g}$ \\
\hline & Apricot purée & $1 / 2$ cup $(125 \mathrm{~mL})$ & $3.1 \mathrm{~g}$ \\
\hline & Mango purée & $1 / 2$ cup $(125 \mathrm{~mL})$ & $1.8 \mathrm{~g}$ \\
\hline & Pear purée & $1 / 2 \operatorname{cup}(125 \mathrm{~mL})$ & $3.2 \mathrm{~g}$ \\
\hline \multirow{4}{*}{ Grains } & Oatmeal porridge & 1 cup $(250 \mathrm{~mL})$ & $4.0 \mathrm{~g}$ \\
\hline & Cream of wheat porridge & 1 cup $(250 \mathrm{~mL})$ & $1.9 \mathrm{~g}$ \\
\hline & Corn grits & 1 cup (250 mL) & $2.4 \mathrm{~g}$ \\
\hline & Bread purée* & $1 / 3$ cup $(85 \mathrm{~mL})$ & $2.0 \mathrm{~g}$ \\
\hline \multicolumn{4}{|c|}{ *Darlington Puréed Bread \& Bakery Mix } \\
\hline
\end{tabular}

\section{How do we achieve a high-fiber puréed diet?}

Puréed diets can be planned to achieve fiber recommendations by choosing higher-fiber puréed foods often. See Table 3 later in this document for an example of a high-fiber puréed foods menu. Alternatively, the fiber content of a puréed diet that is prepared at home or in a care facility can be increased by adding fiber ingredients.

A variety of fiber ingredients are available that can be added to puréed foods. Fiber ingredients can be soluble or insoluble. Soluble fibers dissolve in water. These fiber ingredients can be easily mixed into beverages and most have little to no effect on taste. As puréed foods are high water (see Puréed Food, Thickened Beverages and Water Needs), soluble fibers are easily added to most puréed foods.
Examples of soluble fiber ingredients include:

- Chicory root fiber (also called inulin, oligofructose)

- Fructooligosaccharide

- Corn dextrin

- Hydrolyzed guar gum

- Soy fiber

- Sugar beet fiber

- Wheat dextrin

Insoluble fibers also can be added to some puréed foods, particularly purée-texture grains. For example, the fiber level in oatmeal porridge can be enhanced by adding fiber. Puréed meats and fish are other good choices for the addition of insoluble fiber, as the texture and flavor of the puréed meat and fish tend to mask the added fiber. 
Examples of insoluble fiber ingredients include:

- Bamboo fiber

- Cellulose

- Corn bran

- Cottonseed fiber

- Oat hull

- Pea hull fiber

- Rice bran

Table 3.

HIGH-FIBER MENU

Fiber Content (grams)

\begin{tabular}{|c|c|c|}
\hline \multirow{4}{*}{ Breakfast } & Oatmeal & 4.0 \\
\hline & Scrambled egg purée & 0 \\
\hline & Blueberry Yogurt* & 0 \\
\hline & $1 / 2$ cup mashed banana & 2.9 \\
\hline
\end{tabular}

\begin{tabular}{|c|c|c|}
\hline \multirow{4}{*}{ Lunch } & Salmon Salad & 0 \\
\hline & Puréed Bread† & 2.0 \\
\hline & Creamed Spinach Purée & 1.1 \\
\hline & Puréed Peaches & 1.4 \\
\hline
\end{tabular}

Snack

Cottage Cheese with Pears

3.2

\begin{tabular}{|c|c|c|}
\hline \multirow{5}{*}{ Dinner } & Refried Beans & 6.1 \\
\hline & Whole Grain Corn Grits & 2.4 \\
\hline & Avocado and Salsa Purée & 3.9 \\
\hline & Vegetable Cocktail & 1.9 \\
\hline & Vanilla Pudding & 0 \\
\hline
\end{tabular}

Evening Snack

Peanut Butter \& Jelly Bread Purée†

3.0

Fruit Smoothie

2.0

Total Fiber (grams)

33.9

$\begin{array}{lccc}\text { Salmon Salad } & 0 & 2.0 & 2.0 \\ \text { Puréed Breadt } & 2.0 & - & 2.0 \\ \text { Creamed Spinach Purée } & 1.1 & - & 1.1 \\ \text { Puréed Peaches } & 1.4 & - & 1.4\end{array}$

Supplement Pudding*

0

3.0

- Sugar cane fiber

- Wheat bran (finely ground)

\section{Which fiber ingredients are best?}

If prevention of constipation is the goal, insoluble fibers are the best choices. Insoluble fibers work to bulk the stool. Although many soluble fibers have been shown to have some effect on stool bulking, a much higher intake is

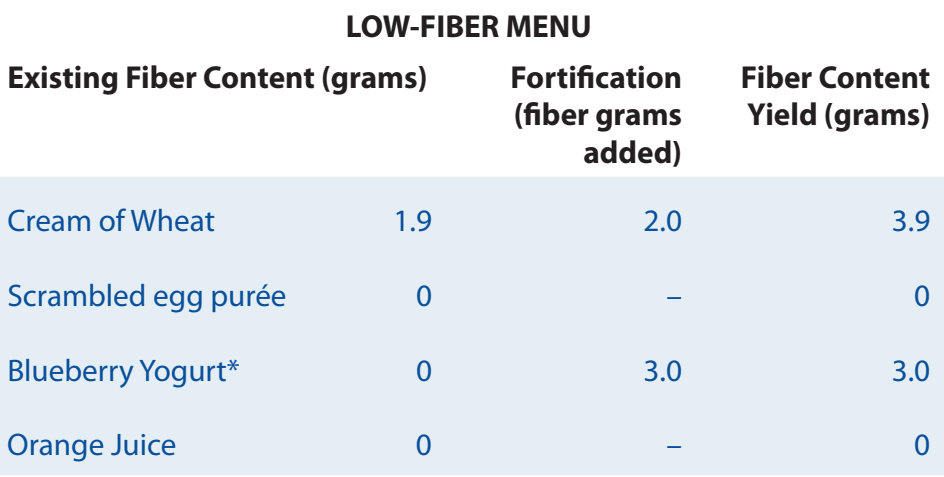

$\begin{array}{lccc}\text { Puréed Chicken } & 0 & 3.0 & 3.0 \\ \text { Mashed Potatoes } & 1.6 & - & 1.6 \\ \text { Puréed Corn } & 1.9 & - & 1.9 \\ \text { Apple Juice } & 0 & - & 0 \\ \text { Vanilla Pudding } & 0 & - & 0\end{array}$

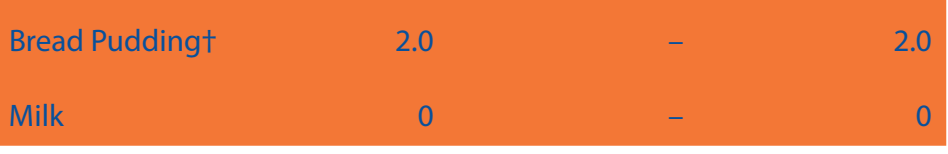

$\begin{array}{llll}\text { Total Fiber (grams) } & 11.9 & 13.0 & 24.9\end{array}$

*Blueberry yogurt without fiber can be substituted for a brand that contains added fiber. A nutritional supplement pudding without fiber can be substituted for one with added fiber. †Darlington Pureed Bread \& Bakery Mix 
required-bran or hull fiber may bulk the stool five times as much as would a soluble fiber (4).

If a prebiotic effect is the goal, however, a soluble fiber such as chicory root fiber is best. Prebiotic fibers promote the growth of what are considered good bacteria in the large intestine, and may enhance health and wellness (5).

If the goal is lowering cholesterol and blood glucose, such as for individuals with diabetes, viscous soluble fibers work best. These fibers, when added to water or when eaten, cause thickening. It is this viscosity or thickening that works best to lower cholesterol and blood glucose. However, these fibers, when added to a puréed food, will cause the food to become too thick (and too sticky) for safe swallowing and should not be used. An example of a viscous fiber is psyllium. Psyllium poses a serious risk for choking for those with swallowing disorders and is not recommended (6). Instead, a food such as oatmeal that naturally contains viscous fiber,can be included in the puréed diet.

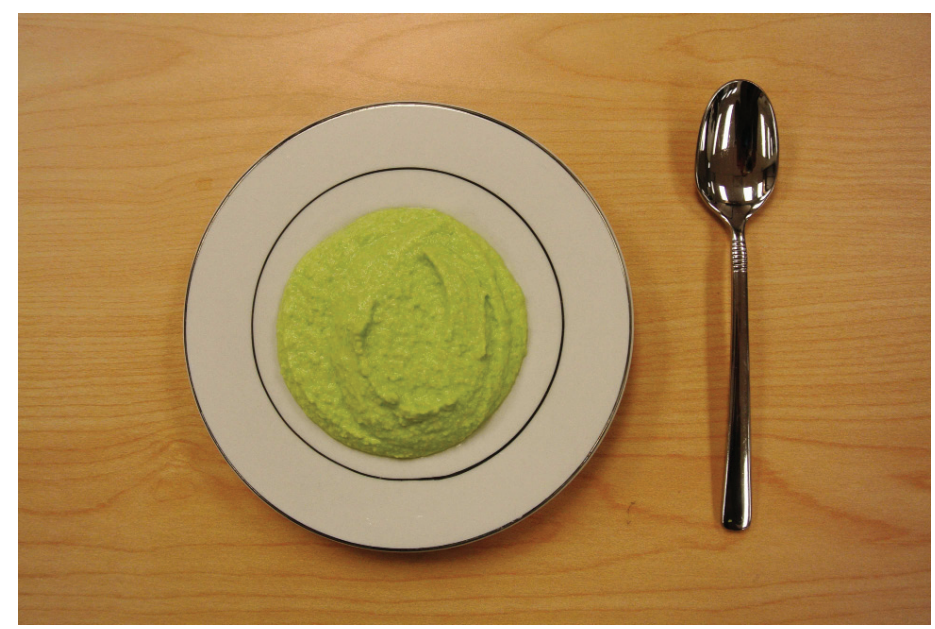

Figure 2. Purée of edamame

Credits: UF/IFAS photo

\section{How much fiber should be added to puréed foods?}

The addition of 10-15 g/day of fiber to a puréed diet would help those consuming the diet in meeting their fiber recommendations. However, adding as little as $4 \mathrm{~g} /$ day of fiber to a long-term care menu has been shown to improve bowel function, particularly in those with constipation (7). Table 3 presents data for a high-fiber puréed menu, along with a lower-fiber puréed menu with and without fiber fortification.

The dietary fiber content of the high-fiber puréed menu is nearly $34 \mathrm{~g}$, exceeding the recommendations for older men and women. The typical low-fiber puréed menu provides only $12 \mathrm{~g}$ of fiber. Substituting yogurt and pudding with similar commercial products containing added fiber, as well as fortifying three foods with an additional $7 \mathrm{~g}$ of insoluble fiber ingredients, brings the fiber level of the low-fiber menu up to nearly $25 \mathrm{~g}$.

The type and amount of fiber added to a puréed food may impact a food's acceptability by changing its taste and texture. It is important to ensure that all foods fortified with fiber are taste-tested for acceptability. See for a guide to evaluating puréed foods for acceptability.

\section{Where can I get more information?}

The Family and Consumer Sciences (FCS) agent at your county Extension office may have more written information and nutrition classes for you to attend. Also, a registered dietitian $(\mathrm{RD})$ can provide reliable information to you.

\section{References}

1. Food and Nutrition Board, Institute of Medicine. 2002. Dietary Reference Intakes for Energy, Carbohydrate, Fiber, Fat, Fatty Acids, Cholesterol, Protein, and Amino Acids. Washington, DC: National Academy Press.

\section{Lengyel CO, Whiting SJ, Zello GA. 2008. Nutrient} inadequacies among elderly residents of long-term care facilities. Can J Diet Pract Res;69:82-88.

3. U.S. Department of Agriculture, Agricultural Research Service. 2012. USDA National Nutrient Database for Standard Reference, Release 25. Nutrient Data Laboratory Home Page, http://www.ars.usda.gov/ba/bhnrc/ndl

\section{Cummings JH, Beatty ER, Kingman SM, Bingham SA,} Englyst HA. 1996. Digestion and physiological properties of resistant starch in the human large bowel. Br J Nutr;75:733-747.

5. Roberfroid M, Gibson GR, Hoyles L, McCartney AL, Rastall R, Rowland I, Wolvers D, Watzl B, Szajewska H, Stahl B, Guarner F, Respondek F, Whelan K, Coxam V, Davicco MJ, Léotoing L, Wittrant Y, Delzenne NM, Cani PD, Neyrinck AM, Meheust A. 2010. Prebiotic effects: Metabolic and health benefits. Br J Nutr;104:S1-S63.

6. NIH. Daily Med Current Medication Information. Available at: http://dailymed.nlm.nih.gov/dailymed/drugInfo. cfm?id=76906 Accessed January 2, 2013.

7. Dahl WJ, Whiting SJ, Healey AD, Zello GA, Hildebrandt SL. 2003. Increased stool frequency and fecal output occurs when finely processed pea hull fiber is added to usual foods consumed by elderly long-term care residents. J Am Diet Assoc;103:1199-1202. 